\title{
Testing grass species and varieties for land reclamation in Iceland
}

\author{
ÁSLAUG HELGADÓTTIR \\ The Agricultural Research Institute Keldnaholti, 112 Reykjavík, Iceland
}

\begin{abstract}
During this century, increasing effort has been put to the reclamation of eroded areas in Iceland, both in the lowlands along the coast and in the interior of the country. The seeding of grass species along with the application of chemical fertilizers has formed the core of the reclamation work. At least $\mathbf{4 5 0}$ different varieties consisting of about $\mathbf{5 0}$ grass species have been tested in variety trials, but only few varieties, all of northern origin, proved valuable. Their performance is strongly dependent on environmental conditions, and it is proposed that a mixture of adapted varieties, subjected to natural selection at each location, would yield better results.
\end{abstract}

Index words: reclamation, northern areas, grass variety trials

\section{Introduction}

Since the settlement of Iceland, 1,100 years ago, much of the former vegetative cover has been lost. At the time of settlement it is believed that $60 \%$ of the country was covered with lush vegetation, whereas today only $25 \%$ of the country is vegetated (Table 1, ThorSTEINSSON 1978). This loss of around 4 million hectars is an extensive degradation of the ecosystem (ARNALDS 1987), and the soil erosion still continues.

Since the turn of the century, serious efforts have been made to halt the erosion and reclaim the lost vegetation (SigurJónSSON 1958). Traditionally, the first step has been to protect the land from grazing. Since 1907, a
Table 1. Changes in vegetative cover in Iceland over 1,100 years.

\begin{tabular}{lcr}
\hline & $\begin{array}{c}\text { At the time } \\
\text { of settlement }\end{array}$ & At present \\
\hline Denuded areas & $18,000 \mathrm{~km}^{2}$ & $58,000 \mathrm{~km}^{2}$ \\
Woodlands & $25,000 \mathrm{~km}^{2}$ & $1,250 \mathrm{~km}^{2}$ \\
Rangelands & $40,000 \mathrm{~km}^{2}$ & $23,000 \mathrm{~km}^{2}$ \\
Cultivated land & & $1,500 \mathrm{~km}^{2}$ \\
\hline
\end{tabular}

total of 210,000 ha have been fenced off, of which 85,000 ha have been protected from grazing since 1974 (RuNólfsSON 1987). In areas of heavy sand drift, Icelandic populations of Elymus arenarius are seeded to stabilize moving sand dunes. After stabilization of 
the soil, the areas are revegetated either through self-seeding or by seeding commercial grass varieties along with the application of fertilizers. Usually, fertilizer is applied for two years in succession. The grass swards that are thus established are expected to aid the natural succession of the native vegetation by providing more hospitable microenvironment. In addition, extensive areas along new highways and in areas disturbed by road construction are seeded yearly. There are no official figures available for the amount of grass seed used for reclamation purposes, but it is probably close to 50 tons per year.

Reclamation by the use of grass seed and fertilizer is very expensive. It is, therefore, important to seed well adapted grass varieties that can persist for a number of years, while the local vegetation is establishing itself. In this paper, important characteristics of grass varieties for reclamation purposes will be identified in the light of the environmental conditions that prevail at the reclamation sites. A brief account will be given of those grass variety trials in Iceland, where the aim has been to search for well adapted grass varieties for this purpose.

\section{Environmental conditions}

Environmental conditions for plant growth are generally harsh in Iceland. This is particularly true in those areas where efforts are being made to revegetate eroded soils, often in the interior of the country.

\section{Climate}

The climate in Iceland can be defined as maritime, cold-temperate in the lowlands, but low arctic in the highlands and in some parts of the lowlands in northern Iceland (EINARSSON 1976). The mean yearly temperature in the lowlands is most commonly between 3.0$4.0^{\circ} \mathrm{C}$, whereas in the highlands it is only around $0^{\circ} \mathrm{C}$ or even less in some areas (Fig. 1). Precipitation varies geographically in Iceland (Fig. 2), and the annual distribution is such that the minimum precipitation occurs in the spring and maximum in the autumn.

\section{Soils}

Soil erosion in Iceland has primarily occurred in the areas of active volcanic eruptions. The soil in the areas which have been termed volcanic loess (SigBJARNARSON 1969) is silty, and the mineral fraction has been deposited by eolian processes. The soil profile is characterized by layers of ash, and it erodes very easily (ARNALDS 1984). In severely eroded areas, the whole profile has blown away, leaving the glacial pavement or old lava flows behind. The soils in these areas are thus coarse, poor in organic matter and available nutrients, and water retention is low (ARNALDS et al. 1987).

\section{Grazing}

The interior of the country is divided into grazing areas for each province and within these areas sheep graze freely for two months during the summer. Grazing has adverse effects on the vegetation in the eroded areas, and where reclamation is in progress the land is protected from grazing by fences. However, fencing is expensive and it would be desirable to be able to revegetate without it.

\section{Important plant characteristics}

A grass variety which is to be used for reclamation purposes must possess a number of characteristics. One of the most important is general adaptation to the climatic environment. Under the conditions which prevail in the areas of reclamation, winterhardiness is probably the most important feature. Poorly adapted varieties most commonly die in the first or second winter after sowing. This can be related to the onset of dormancy in the autumn, as a close association between growth cessation and winter survival has been found for latitudinal ecotypes of both Poa pratensis and Festuca rubra (KLeBESADEL et al. 
Temperature,

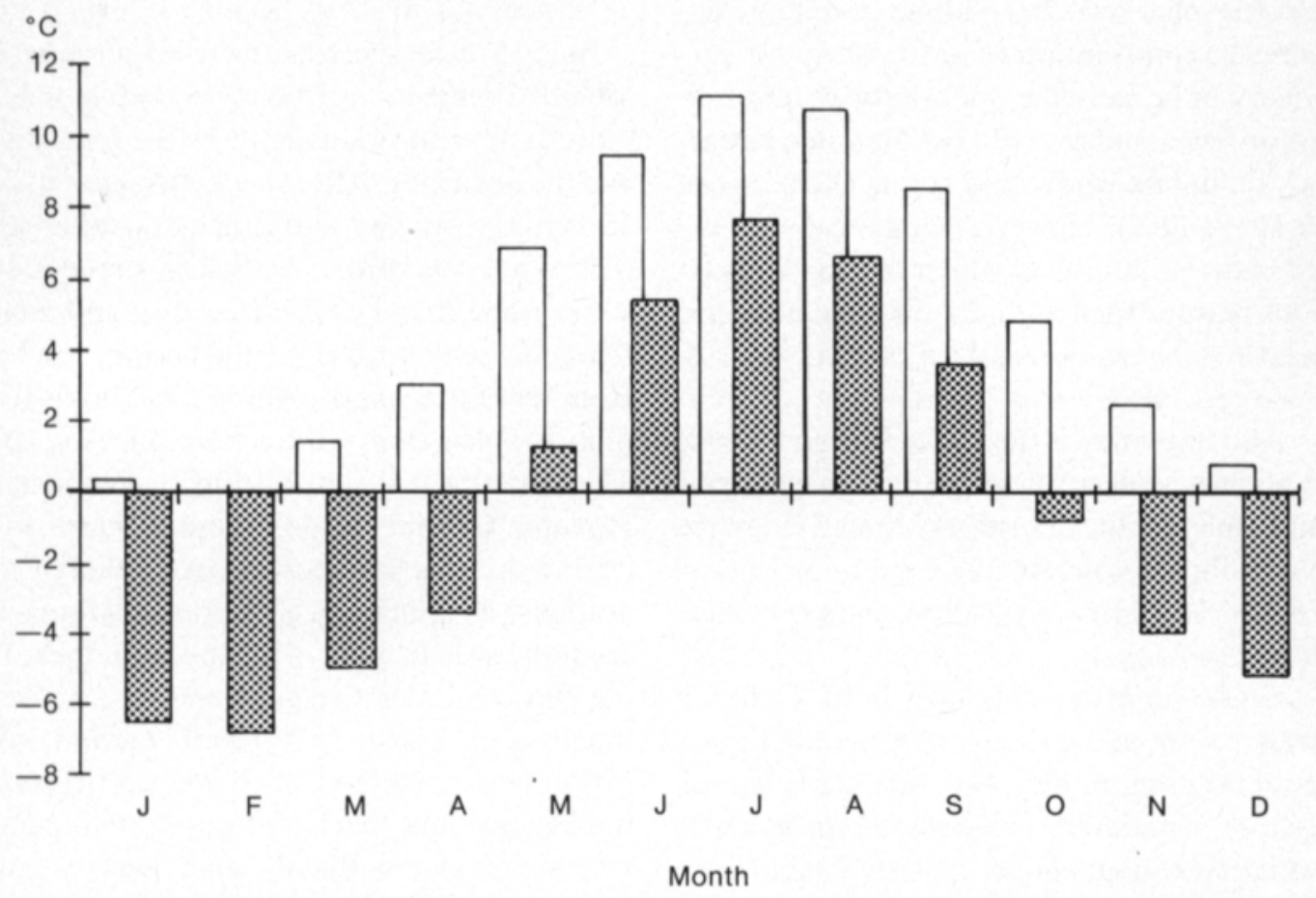

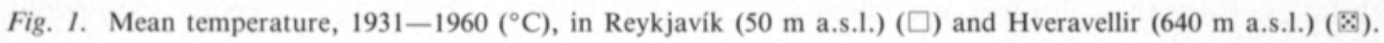

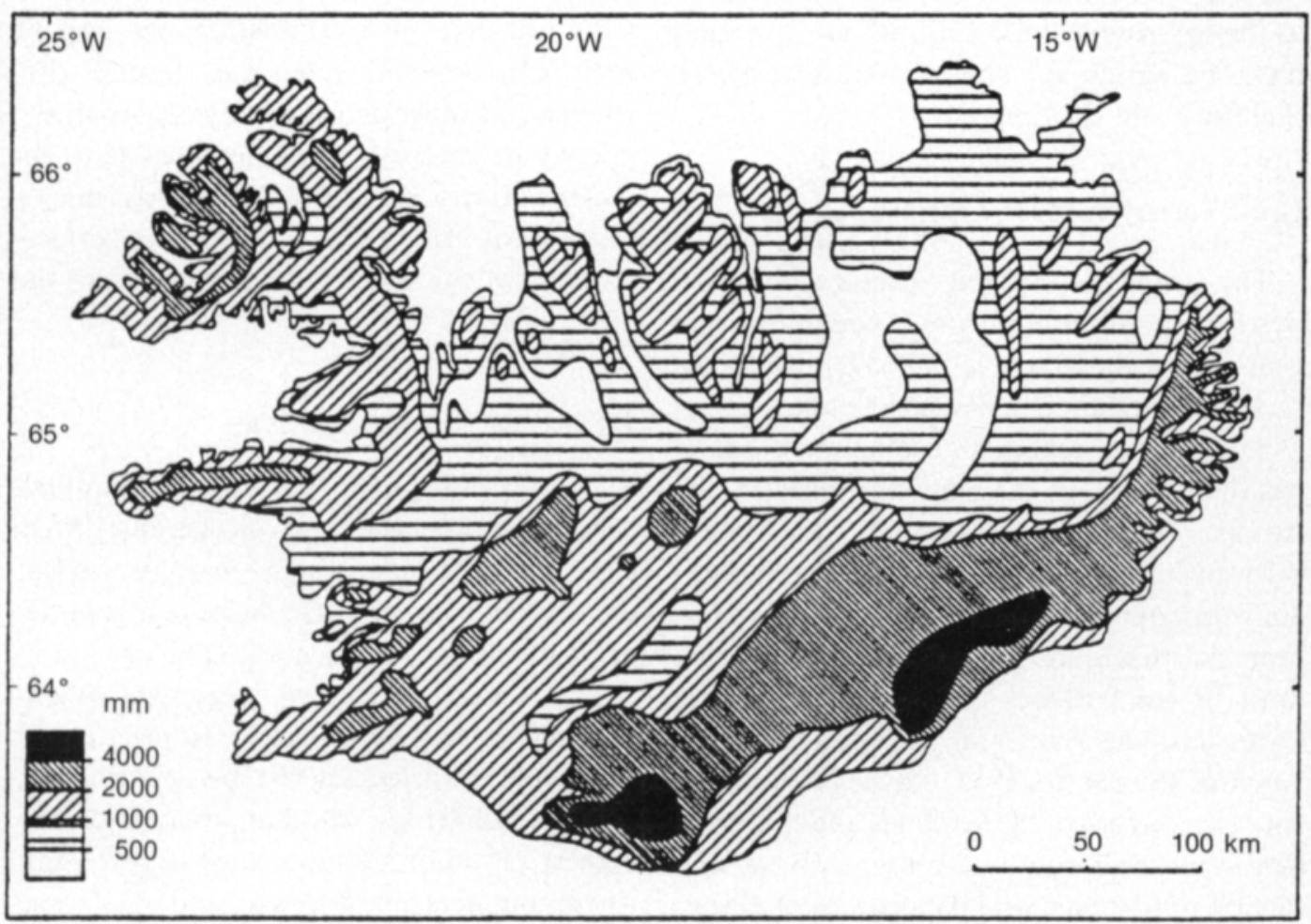

Fig. 2. Mean precipitation, 1931-1960 (mm). (BERGTHórsson 1988). 
1964, HẢBJøRg 1979). Small plants can persist for some years but without giving any significant contribution to yield. The poor survival can be caused by poor growth and lack of sufficient nutrient reserves resulting in starvation in late winter and spring (KLEBESADEL \& Helm 1986). However, climatically adapted material can suffer winter damage for various reasons such as direct frost damage, soil heaving, desiccation and ice cover (LARSEN \& Ảrsvoll 1984).

Also important is the ability to bind the soil, especially in areas where soil movement is considerable. Other desirable characteristics are the ability to tolerate low fertility or lack of chemical fertilizer application, and persistence under grazing.

Grass varieties that have been used for reclamation in the past have generally shown poor persistence. This was particularly true of Danish varieties of red fescue (Festuca rubra) which were used almost exclusively for many decades. Even though more persistent varieties have been used recently, reclamation using seed and fertilizer remains haphazardous as the environmental conditions are so variable. The search for superior grass varieties therefore still continues.

\section{Grass variety trials for reclamation}

The search for suitable species and varieties for reclamation purposes began over 40 years ago (SigurJónSSON 1958). Until recently, seed of Icelandic grass varieties has generally not been available. Introduction breeding has therefore been the main approach in the variety testing, as for example in Alaska (Mitchell 1982), even though a few Icelandic wild populations and bred varieties have been included in the trials. In the earlier trials, most of the varieties tried originated from lower latitudes, either in Europe or NorthAmerica (Sveinsson 1953). Most of the varieties tested, both in the lowlands and the highlands, survived only two years, with the exception of Icelandic wild populations of Festuca rubra, Poa pratensis and Deschampsia caespitosa (e.g. FriDRIKSSON 1952, 1971, ArNALDS et al. 1978).

In 1975, extensive trials were begun, where 403 different grass varieties were sown in small plots at four locations both in the lowlands and the highlands. After two winters, less than $25 \%$ of the varieties sown still had some cover (ARnAlds et al. 1978). The best 46 varieties of six species, mainly Festuca rubra and Poa pratensis, were selected on the basis of results from these trials and sown in 1980 in bigger plots in a new trial at three locations (Fig. 3). The varieties originated from Scandinavia, Holland, Germany and the United States, including Alaska. The locations were chosen so as to give a variation in elevation and distance from the sea. In 1981, a smaller trial including 10 varieties of five grass species was laid out in three places in northern Iceland, all $500 \mathrm{~m}$ above sea level. This was carried out in conjunction with a hydro-power station development in the Blanda area, where new grazing areas are needed to replace rangelands that will go under water (HelgadótTIR 1988). In the former trial, all plots were protected from grazing, but in the latter, one half of each experimental plot was fenced off, whereas the other half was subjected to heavy grazing by sheep. It was thus possible to assess the effects of grazing on the performance of the grass varieties. In both trials the effects of fertilizer shortage on the persistence of the grass varieties were studied.

\section{Differences between varieties}

The results from the trial established in 1980 demonstrate that there are considerable differences in performance between varieties, but the display of these differences is highly dependent on the test location (Fig. 4).

The test sites provided a gradient of environmental conditions with least discrimination between varieties at the lowest elevation, Gunnarsholt (Fig. 4a), but greatest at the highest elevation, Hrauneyjafoss (Fig. 4c), where summers are short and cold. The snow cover is restricted in this area so that the grass 


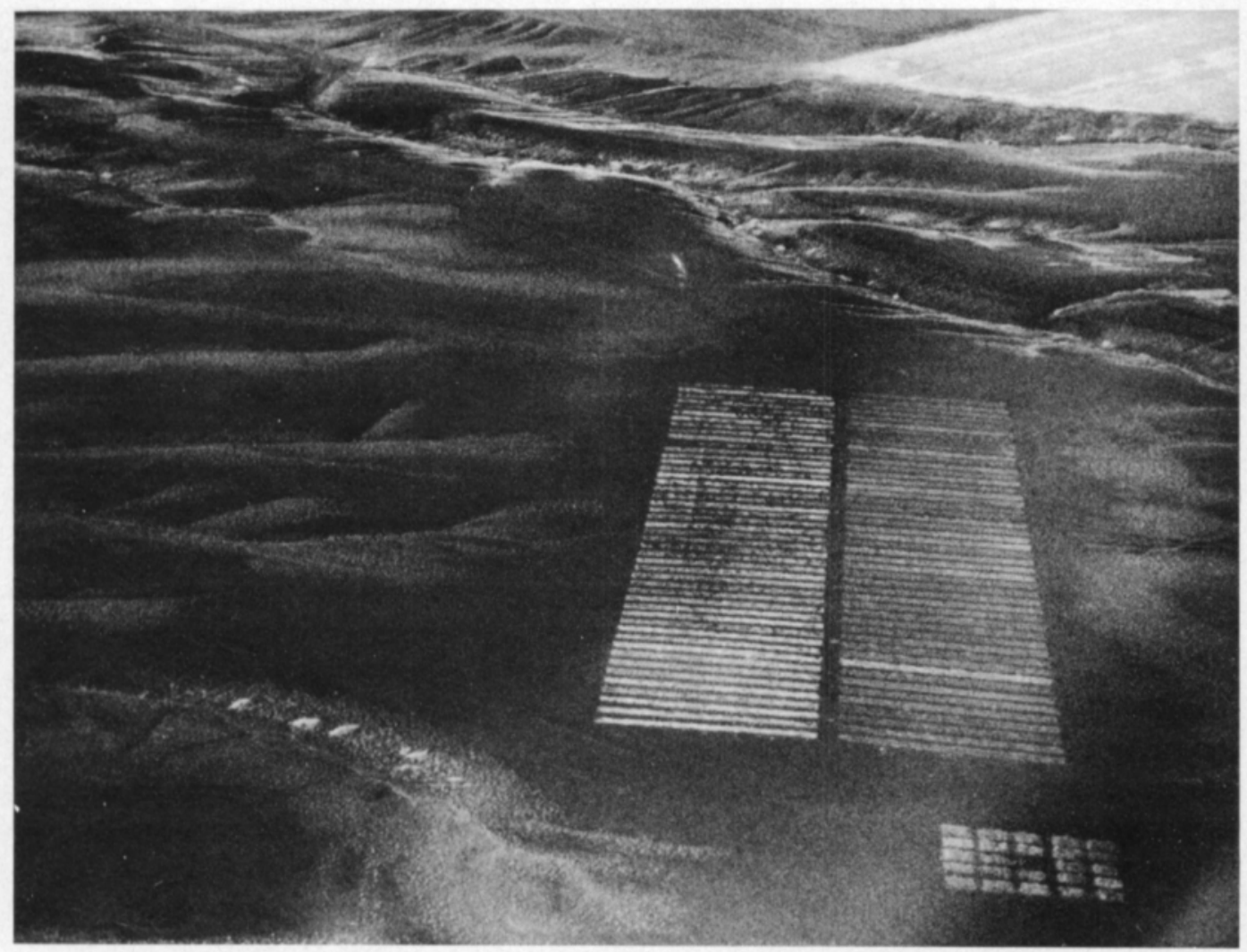

Fig. 3. Grass variety trials at Gunnarsholt. Each plot is $100 \mathrm{~m}^{2}$. The plots on the right are fertilized whereas those on the left are unfertilized.

is subjected to severe frost. Using such an environmental gradient makes it possible to discriminate between varieties subjected to different levels of stress.

Very few grass varieties are hardy enough to survive the harsh conditions that prevail at the experimental sites, especially those at Hrauneyjafoss. The varieties that did survive are all of northerly origin, namely, Deschampsia beringensis, IAS 19 from Alaska, Deschampsia caespitosa, a wild population from Iceland, Festuca rubra, Leik from Norway and Sturla and 0305 from Iceland. Varieties of Poa pratensis were in general inferior, but of these Fylking from Sweden had an advantage.

In the smaller trial in the Blanda area, only the eight most promising varieties of the big trial were included in addition to Festuca rubra Echo from Denmark and Festuca ovi- $n a$ Tournament from Holland, both of which soon disappeared. The performance of the other varieties varied somewhat between years and locations (Fig. 5a). On the plots which were protected from grazing, D.beringensis and D.caespitosa were generally superior to others and it seems that the Icelandic varieties of both F.rubra and P.pratensis had become superior to imported varieties towards the end of the experiment.

These results correspond well with results from variety trials in other northern regions, for example in Alaska (Klebesadel 1985). Most of the varieties that fail originate from lower latitudes and are thus adapted to different photoperiodic conditions in autumn. They misread the photoperiodic signals and, consequently, have not developed adequate hardening at the onset of winter. The climatic conditions within the same latitude are also 


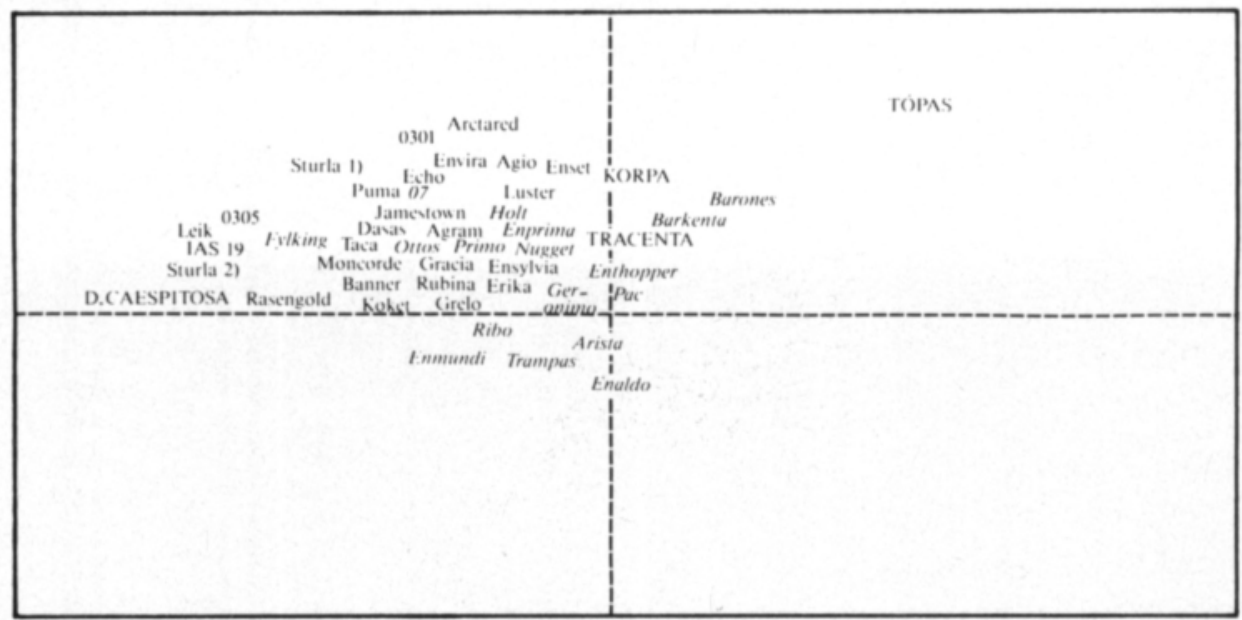

\section{(b) Búrfell (160 m a.s.l.)}

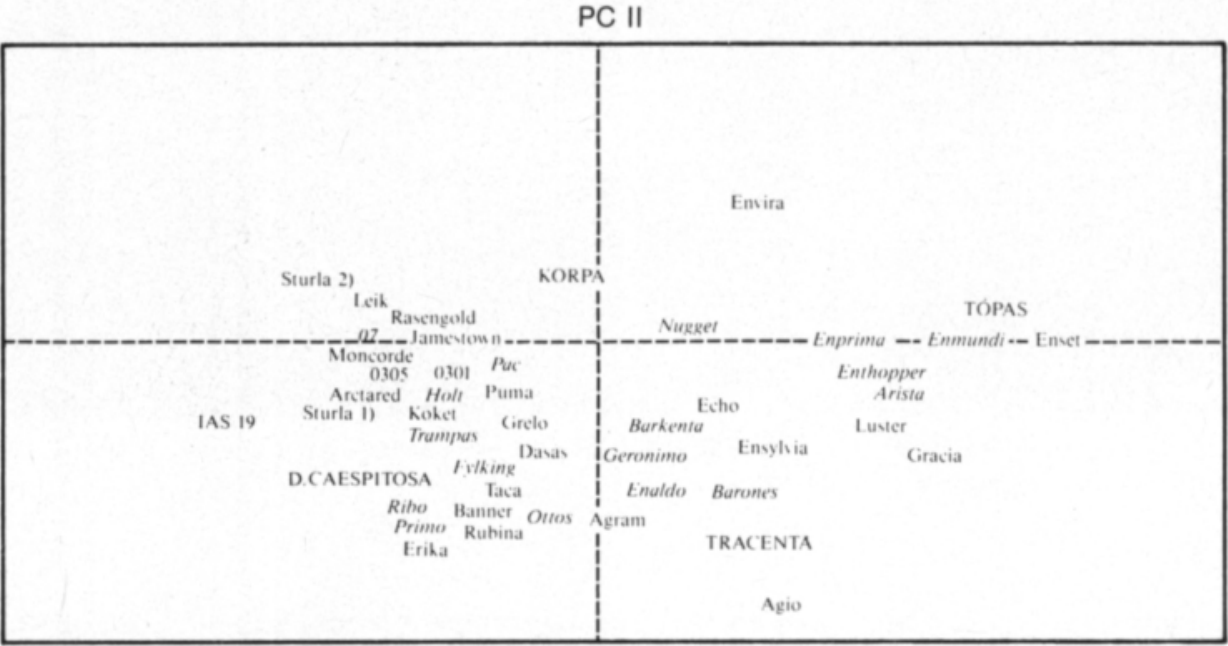

(c) Hrauneyjafoss (420 m a.s.I.)

PC II

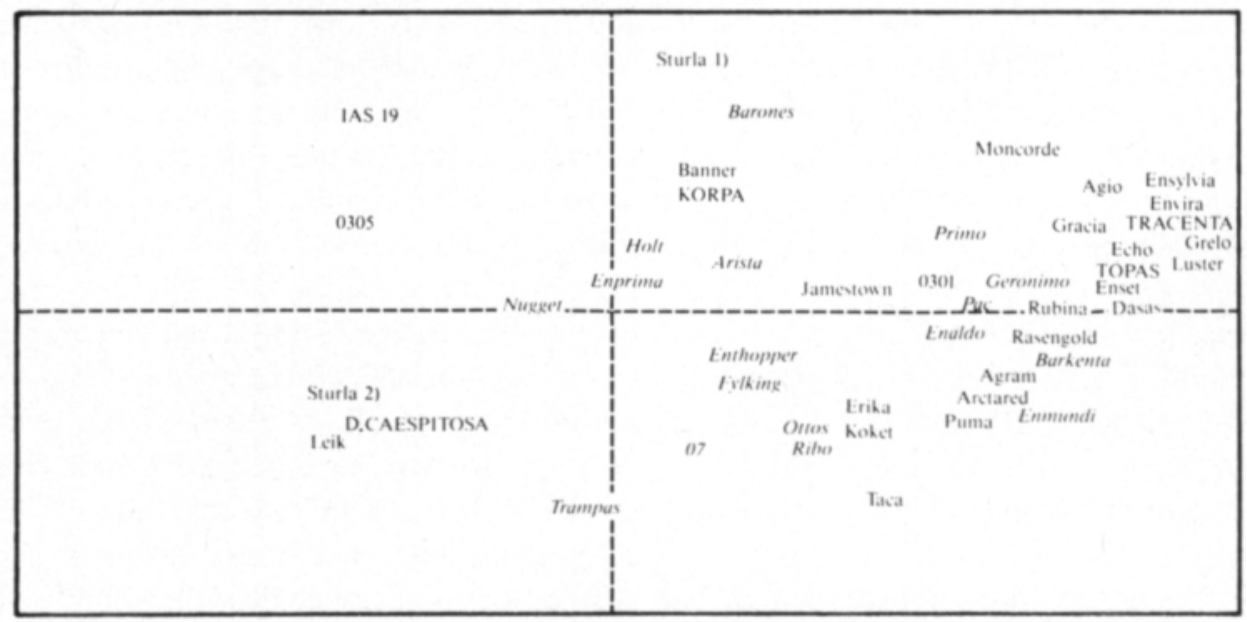

Fig. 4. Evaluation of grass varieties on fertilized plots in a variety trial from 1980 in Iceland, using Principal Components Analysis combined for all three locations. The analysis is based on six variables, and PC I and PC II explain $74 \%$ and $12 \%$ of the total variation, respectively. The varieties with the lowest scores on PC I showed the greatest persistence and vigour. Varieties of F.rubra are represented by ordinary letters, P.pratensis by italics and other species by capital letters (Helgadótrir 1988). 
Cover

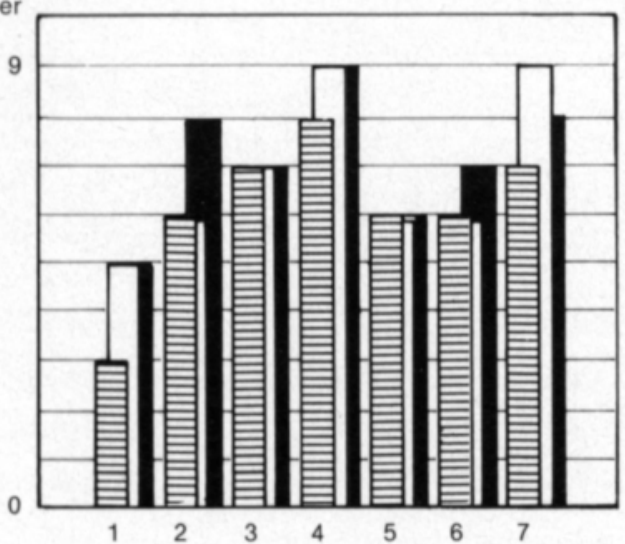

Seyðisá (600 m a.s.I.)
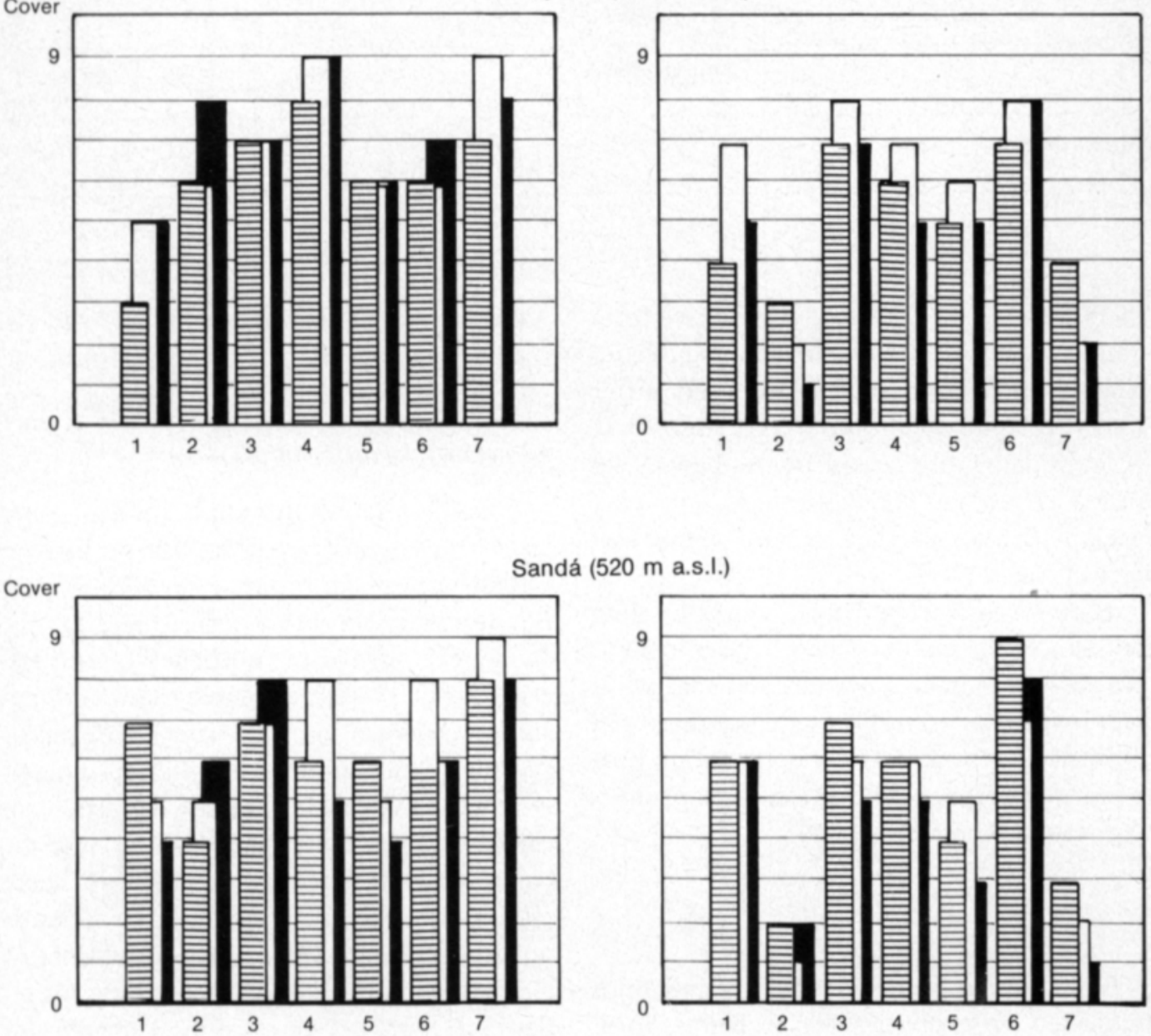

Sandá (520 m a.s.l.)

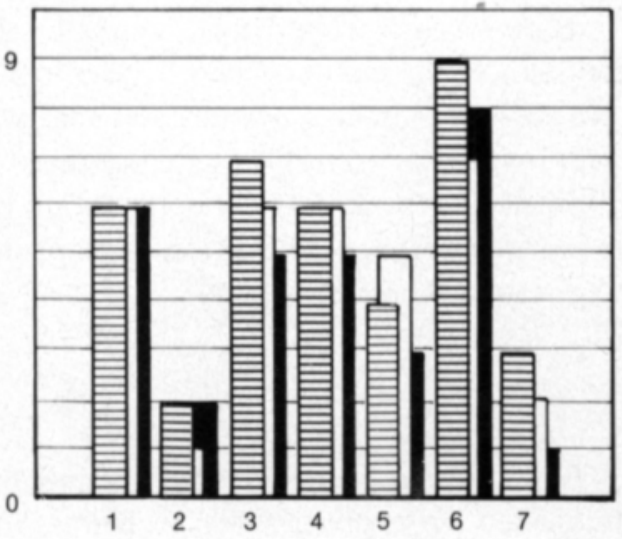

Öfuguggavatushæðir (500 m a.s.I.)
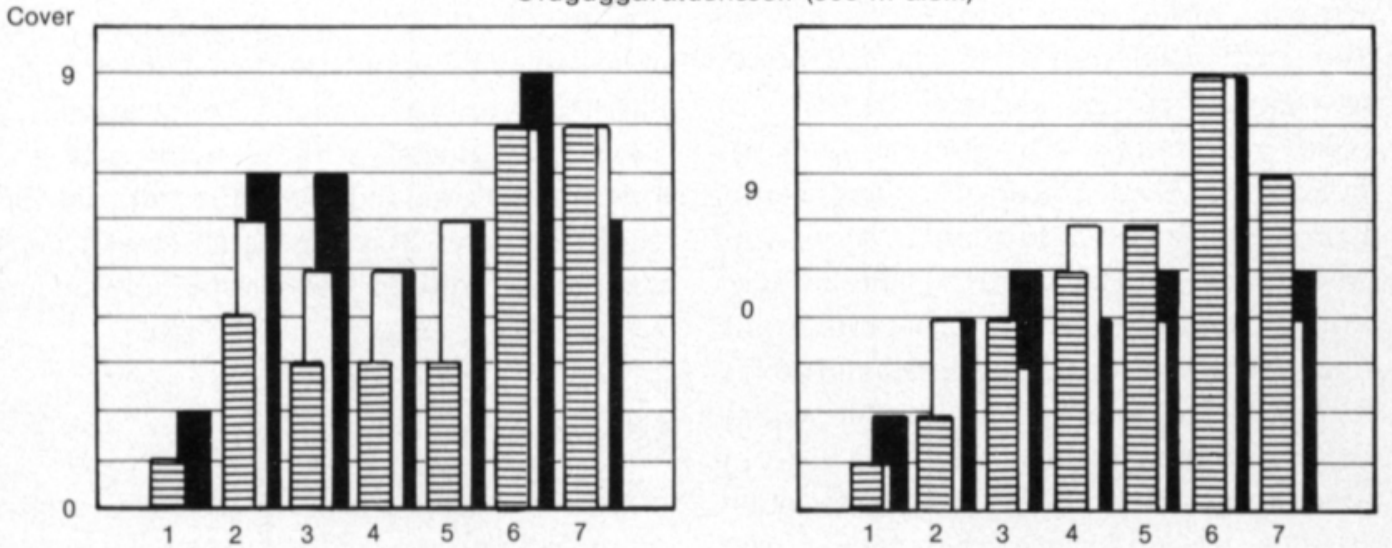

Fig. 5. Cover $(0-9 ; 0=$ no cover, $9=$ full cover $)$ of grass varieties, on fertilized plots in a trial established in

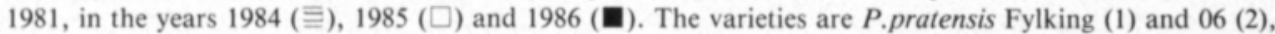
F.rubra Sturla (3), Leik (4) and 0301 (5), D.caespitosa Icelandic wild population (6) and D.beringensis IAS 19 (7). (HelgadótTir 1988). 
Table 2. The effects of fertilizer stress on cover $(0-9 ; 0=$ no cover, $9=$ full cover $)$ of varieties of Festuca rubra and Poa pratensis in variety trials in southern Iceland.

\begin{tabular}{lccccc}
\hline & \multicolumn{2}{c}{ Fertilized plots } & \multicolumn{2}{c}{ Unfertilized plots } \\
& F.rubra & P.pratensis & F.rubra & P.pratensis \\
\hline Mean cover & 5.9 & 5.6 & 2.0 & 3.9 \\
s.e. & 1.90 & 1.21 & 1.58 & 1.72 \\
\hline
\end{tabular}

of importance. Varieties that originate from comparable latitudes but are adapted to continental climates or stable winters may suffer under Icelandic conditions, where the climate is maritime with repeated freeze-thaw cycles in winter, even at higher altitudes. This may explain why not all Alaskan material fare well in Iceland.

D.beringensis from Alaska is an interesting addition to the species - poor Icelandic flora, which only numbers around 400 species. It was first imported in 1974 and has since been extensively tested, both for reclamation purposes and herbage production, with promising results (TómASsON 1984).

\section{Effects of grazing}

In the smaller trial, where the varieties were subjected to severe grazing pressures, their relative performance altered substantially (Fig. 5b). The Icelandic wild population of D.caespitosa surpassed all other varieties, whereas D.beringensis and P.pratensis 06 from Iceland suffered most. The differences between these species can largely be explained by different root patterns. Another study has revealed that D.caespitosa has a significantly higher root/shoot ratio than D.beringensis (Magnússon \& Helgadóttir, unpublished results) causing the former to sit more firmly in the soil. Plants of D.beringensis and 06, on the other hand, were torn up from the soil by the grazing animals. In addition, the tillers of D.beringensis are erect and the growing point sits above the soil surface. This contrasts with D.caespitosa, which has dense tillers, a growing point below the soil surface and prostrate leaves. Consequently, the grazing animal is not able to reach the whole plant, allowing the remaining leaves to carry on photosynthesis.

\section{Effects of fertilizer stress}

It has been shown that application of chemical fertilizer generally affects the persistence of sown grasses in reclamation (GunNLAugsDóTTIR 1985). This is not surprising, since the soil is generally poor in nutrients. In the variety trials of 1980 , it appeared that P.pratensis was generally more persistent to fertilizer shortage than F.rubra (Table 2) (HelgadótTIR 1988). The former species has extensive rhizomes, where nutrient reserves may accumulate when nutrients are plentiful. These reserves can then be remobilized at times of nutrient shortage. There is indeed evidence of old reclamation trials where Icelandic varieties of P.pratensis have survived for a number of years without any fertilizer (ARNALDS et al. 1978). F.rubra, on the other hand, has no such storage system and may therefore be able to tolerate fertilizer shortage less well. Wild Icelandic populations of D.caespitosa have survived in a number of reclamation trials in the highlands without fertilizer (FRIDRIKSSON 1971) and in the most recent trials in the Blanda area it surpassed all other varieties under fertilizer stress, especially under heavy grazing (HelgadótTIR 1988).

\section{Conclusions}

Extensive variety trials in Iceland demonstrate that only grass varieties of northerly origin are adapted to the conditions that prevail where reclamation is in progress. However, their performance strongly depends on en- 
vironmental conditions such as climatic factors, soil type, snow cover and presence of grazing animals. It has, therefore, been proposed to sow a mixture of adapted grass varieties for reclamation and let nature select the most suitable combination at each location.
To test this hypothesis, a new experiment has been started, where mostly Icelandic material is seeded in various combinations with different amounts of fertilizer, with and without grazing.

\section{References}

Arnalds, A. 1987. Ecosystem disturbance and recovery in Iceland. Arct. Alp. Res. 19: 508-513.

-, Árnason, Th.Ö., Lawrence, Th. \& Sigurbuornsson, B. 1978. Grass variety trials for reclamation and erosion control. RALA Report No. 37. 52 p.

Arnalds, Ó. 1984. Eolian nature and erosion of some Icelandic soils. J. Agr. Res. Iceland. 16: 21-35.

-, Aradóttir, Á.L. \& Thorsteinsson, I. 1987. The nature and restoration of denuded areas in Iceland. Arct. Alp. Res. 19: 518-525.

Bergthorsson, P. 1988. The effects of climatic variations on agriculture in Iceland. 1. Introduction. In: The Impact of Climatic Variations on Agriculture. Volume 1. Assessments In Cool, Temperate and Cold Regions (Eds. M.L. Parry, T.R. Carter \& N.T. Konijn). Kluwer Academie Publishess Group, The Netherlands.

Einarsson, M.Á. 1976. Veðurfar á Íslandi (Weather in Iceland). 150 p. IOunn, Reykjavík.

Fribriksson, S. 1952. Comparison of some agronomically significant properties of grasses grown at four sites in Iceland. Report No. 2 from The University of Iceland, Dept. of Agriculture.

- 1971. Ræktunartilraunir á Kili (Land reclamation studies in the district Kjölur, Central Iceland). J. Agr. Res. Iceland. 2: 34-49.

GunNLAugsDóttır, E. 1985. Composition and dynamical status of heathland communities in Iceland in relation to recovery measures. Acta Phytogeographica Suecica 75. Uppsala. 84 p.

Helgadóttir, Á. 1988. In search of suitable grass varieties for reclamation purposes in Iceland. Icel. Agr. Sci. 1. In press.

KLeBesAdel, L.J. 1985. The critical importance of northlatitude adaptation for dependable winter survival of perennial plants in Alaska. Agroborealis 17: 21-30.
— \& Helm, D. 1986. Food reserve storage, low-temperature injury, winter survival, and forage yields of timothy in subarctic Alaska as related to latitude-of-origin. Crop Sci. 26: 325-334.

-, Wilton, A.C., Taylor, R.L. \& Koranda, J.J. 1964. Fall growth behaviour and winter survival of Festuca rubra and Poa pratensis in Alaska as influenced by latitude-of-origin. Crop Sci. 4: 340-341.

Larsen, A. \& Ảrsvoll, K. 1984. The impact of biotic and physical overwintering factors on grassland production and management. In: The Impact of Climate on Grass Production and Quality (Ed. H. Riley and A.D. Skjelvåg). Proc. 10th General Meet. EGF, Norway, 268-277.

Mitchell, W.W. 1982. Forage yield and quality of indigenous and introduced grasses at Palmer, Alaska. Agron. J. 74: 899-905.

Runólfsson, S. 1987. Land reclamation in Iceland. Arct. Alp. Res. 19: 514-517.

Sigbjarnarson, G. 1969. Áfok og uppblástur (The loessial soil formation and erosion on Haukadalsheiði). Náttúrufræðingurinn. 39: 49-128. (English summary).

Sigurjónsson, A. (Ed.) 1958. Sandgræðslan. Minnst 50 ára starfs Sandgræoslu rikisins (Celebration 50th Anniversary Soil Conservation Service of Iceland). Agric. Soc. Icel. and Soil Cons. Serv. Icel. 359 p.

Sveinsson, R. 1953. A memorandum on soil erosion and reclamation problems in Iceland. Mimeograph. Soil Cons. Icel. $36 \mathrm{p}$.

Thorsteinsson, I. 1978. Gróður og landnýting (Vegetation and land utilization). Lesörk Landverndar, 3. Reykjavik. 45 p.

Tómasson, Th. 1984. A grass from Alaska gives promising results in Icelandic trials. Agroborealis 1984: $33-36$. 


\section{SELOSTUS}

\section{Maan kasvuunpalauttamisessa käytettävien}

heinälajien ja -lajikkeiden testaaminen

\section{Islannissa}

\section{Áslaug Helgadóttir}

The Agricultural Research Institute

Keldnaholti, 112 Reykjavik, Iceland

Islannissa on 1900-luvun mittaan panostettu lisääntyvăssä määrässă toimenpiteită erodoituneiden alueiden saattamiseksi uudelleen kasvuston peittoon. Työn perustan on muodostanut eri heinälajien kylväminen ja viljeleminen kemiallisia lannoitteita kåyttảen. Kenttäkokeissa on tutkittu vähintään 450 lajiketta noin 50

heinălajista, mutta vain muutamat, pohjoista alkuperăă olevat lajikkeet ovat osoittautuneet käyttökelpoisiksi. Lajikkeiden menestyminen on voimakkaasti riippuvainen ympäristöoloista ja onnistuneen tuloksen saavuttamiseksi suositellaan sopeutuneiden lajikkeiden seosviljelyä eri paikoilla vallitsevan luonnonvalinnan alaisena. 